\title{
INVESTIGATING CITIZENSHIP BEHAVIOR EFFECTIVENESS AND EXTENDING THE EFFECTIVENESS OF PROJECT IMPLEMENTATION IN LIGHT OF THE COVID-19 PANDEMIC
}

(iD) Thanawatdech
Thirapatsakun $^{1+}$
(iD) Piyachat
Jarutirasarn $^{2}$

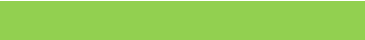

Article History

Received: 1 October 2021

Revised: 18 November 2021 Accepted: 3 December 2021 Published: 16 December 2021

\section{Keywords}

OCB

Temporary organization

Helping behavior

Project loyalty

Project-based compliance

Relationship maintenance

Construction project

Oil and gas industry

Thailand.

\section{JEL Classification}

D220; L2 10; L740; M120.

\author{
${ }^{\prime}$ Ph.D., special instructor in the Department of General Management, \\ Faculty of Business Administration, Ramkhamhaeng University, Bangkok, \\ Thailand. \\ Email: thanawatdech19@gmail.com Tel:+6661898-2225 \\ ${ }^{2}$ Ph.D., Prof. Department of General Management, Faculty of Business \\ Administration, Ramkhamhaeng University, Bangkok, Thailand. \\ Email:Piyachat.j@rumail.ru.ac.th.Tel:+6689799-1925
}

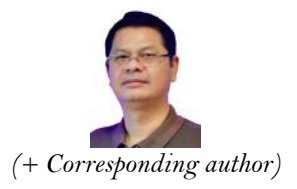

ABSTRACT

Contribution/Originality: This research contributes to the existing literature by providing valuable information for policymakers regarding how facilitators and inhibitors influence large-scale construction projects in the oil and gas industry.

\section{INTRODUCTION}

The pandemic has disrupted many aspects of daily life and citizens have had to ensure prolonged periods of lockdown, with governments restricting or banning almost all forms of face-to-face contact outside immediate family. This has led to an unprecedented impact on people's mental health (Singh, Tang, Zhang, \& Zheng, 2020; Tubadji, Boy, \& Webber, 2020). Meanwhile, many organizations have attempted to maintain operations during the pandemic. The cultural and economic impacts of the virus have created a "new normal" within the COVID era, which has resulted in a radical transformation of the way that people interact and operate within the workplace that could potentially influence many facets of our daily lives for the foreseeable future (Griffin \& Denholm, 2020). Whilst many companies have been forced to close down or drastically reduce operations, those organizations that have continued to operate have needed to work within a changing landscape of new processes and practices influenced by social distancing requirements and altered work patterns (Richter, 2020). Many organizations have 
been forced to adopt new ways of communication and completely rethink their business models to adapt to the realities of the COVID-19 environment. Hence, the top management and managers have undertaken responsibilities in response to the crisis to keep the right employees. Employees are the most valuable asset in any organization to survive through the global pandemic and economic crisis. Both academic researchers and practitioners have intensified their level of interest in employee relations within organizations during the pandemic. Entrepreneurial and organizational needs and the citizenship behavior effectiveness (CBE) have been linked to the effectiveness of project implementation (EPI), which is acute during workplace changes. The theory of the effectiveness of project implementation was adapted primarily from the project implementation profile (PIP) of Pinto \& Slevin (1988). Action has shaped the variables of extended project mission (PM), top management support (TMS), project schedule/plan (PSP), client consultation (CC), personnel (PSN), technical tasks (TT), client acceptance (CA), monitoring and evaluating (MFB), communication (COM), and troubleshooting (TBS). Some studies have tested citizenship behavior effectiveness (CBE). This theory was adapted primarily from citizenship behavior effectiveness (temporary organization) by Braun, Ferreira, \& Sydow (2013). The constructs and actions shaped the variables of helping behavior (HB), project loyalty (LO), project-based compliance (PC), individual initiative (INI), and relationship maintenance (RM). This study will provide insights into citizenship behavior effectiveness (CBE), how it exerts an extended mediation effect on the effectiveness of project implementation (EPI), and the application of different methods. In the following discussion, we use $\mathrm{CBE}$ as an independent variable that can influence EPI, the dependent variable. To the best of our knowledge, the relationship between CBE and EPI has several different perspectives which have not yet been explored. Addressing that gap is one of the objectives of this paper. The hypotheses were developed and tested using a sample of 385 employees working on construction projects in the oil and gas industry. The research results provide good support for these hypotheses.

\section{LITERATURE REVIEW AND HYPOTHESES DEVELOPMENT}

Valuable insights into citizenship behavior effectiveness (CBE) include the conceptual development of the citizenship behavior dimension in temporary organizations, having indicated that employee relationships are vital for the effectiveness of project implementation. The adapted theory is primarily taken from the project implementation profile (PIP) of Pinto \& Slevin (1988), and the views of citizenship behavior effectiveness theory (temporary organizations) were adapted primarily from Braun et al. (2013). Nevertheless, we need to fully assess how vital these relationships are before we can conceptualize and measure them accurately. In the following discussion, we use citizenship behavior effectiveness (CBE) as an independent variable that can influence the effectiveness of project implementation (EPI), which is the dependent variable. The previous evidence from researchers of the relationship between $\mathrm{CBE}$ and EPI has several different perspectives.

\subsection{Citizenship Behavior Effectiveness (CBE)}

The conceptual development of the citizenship behavior dimension in temporary organizations is a dictator of citizenship behavior effectiveness (CBE). There is empirical evidence adopted primarily from that organizational citizenship behavior (OCB) does not just promote effective outcomes. (Organ, Podsakoff, \& MacKenzie, 2005); it also increases the social capital in organizations, improving the relationship quality among co-workers and increasing trust (Bolino, Turnley, \& Bloodgood, 2002). The findings of construct dimensions demonstrate their relevance in this context (Braun et al., 2013). Helping behavior: This is defined by Podsakoff, MacKenzie, Moorman, $\&$ Fetter (1990) as behavior directed towards helping people in problematic situations. The intention to assist coworkers in a temporary organization when solving problems is, in some cases, to allow a co-worker to fix a problem even though it is not part of any contract. The conceptual development process is adapted from Autry, Skinner, \& Lamb (2008) and is specified for temporary organizations. This dimension appears directed towards individuals or the entire project team, who often have formal work contracts with different organizations. Such project-specific 
helping behavior is essential in temporary organizations (Braun et al., 2013). Project loyalty: This is defined as organizational loyalty based on a description by Van Dyne, Graham, \& Dienesch (1994) and was adjusted by Autry et al. (2008), and is defined as behavior directed towards helping a person face-to-face in problematic situations, defending the temporary organization if it criticized from external sources. Braun et al. (2013) adopted contextsensitive project loyalty dimensions as an allegiance to the temporary organization as a whole, sometimes, but not necessarily, sacrificing one's own interests or those of the organization for the common good. Organizational loyalty supports and defends corporate objectives (Borman \& Motowidlo, 1997). Some characteristics include spreading goodwill, protecting the organization and defending it against threats, even in adverse conditions (Podsakoff et al., 1990). Rhoades \& Eisenberger (2002) mentioned that employment is the trade of effort and loyalty for tangible benefits and social rewards. Autry et al. (2008) and Braun et al. (2013) applied this dimension to temporary organizations; the significant difference here is a directive to organizational belonging to a parent organization, which can conflict with belonging to a temporary organization. Team members often hold employment contracts with their parental organizations, and therefore have to report to their line managers. Temporary organizations create a second reference point for loyalty.

Project-based compliance: Autry et al. (2008) and Braun et al. (2013) describe adherence to the rules, policies, and processes as a form of conscientiousness that is indirectly helpful to others; doing what a good employee ought to do - adhering to the quality standards of a project and issuing regular project charter statements of work required by project managers. In addition, prescribed tasks are dictated by organizational policy and job descriptions (Wong, Ngo, \& Wong, 2006). The pandemic has been disruptive; many projects are "virtual operations", and project participants can collaborate over the internet, telephone and social networks. In this context, cases where nobody is watching compliance issues is the rule rather than the exception. Objects of compliance are, in the project context, for instance, communication procedures, information sharing policies, deadlines and punctuality (Braun et al., 2013).

Individual initiative: Staufenbiel \& Hartz (2000) described this as going beyond what is required and volunteering to take on additional responsibilities. Furthermore, employees show enthusiasm, tackle other tasks and motivate fellow employees to do the same (Podsakoff., MacKenzie, Paine, \& Bachrach, 2000). As for temporary organizations, this dimension appears to perform creative and innovative functions beyond contractual arrangements, i.e., making suggestions for improvements to processes and services. Project participants proactively use their knowledge of past projects to make suggestions for improvements in current projects without being asked to do so (Autry et al., 2008; Braun et al., 2013). Relationship maintenance: This is described by Autry et al. (2008) and Braun et al. (2013) as employees keeping in contact with co-workers even beyond termination of employment. However, an employee's overarching interest and commitment are towards the organization (Podsakoff et al., 2000). OCB is prevalent even in short-term work, cuts across organizational boundaries, and exists under the socially ambiguous standing of personnel (Blatt, 2008). Employees keep in contact with former colleagues via social networks and phone, and regularly meet up/have conversations to keep the relationship alive (Braun et al., 2013).

\subsection{Citizenship Behavior Effectiveness (CBE) and the influence of the effectiveness of project implementation (EPI)}

There is also some evidence that the value sought from a high performing project management system is associated with the effectiveness of projects. The organization needs to know what factors are critical for effective project implementation. This model provides an effective project implementation profile (PIP), which occurs when projects are evaluated using a PIP as a way of demonstrating relative citizenship behavior effectiveness (CBE) and the influence of the effectiveness of project implementation (EPI). Next, we discuss the ten aspects of the effectiveness of project implementation process. Project mission: This refers to the clarity of goals and general directions for a project from the outset. Before a project starts, it is vital to have a clear, well-acknowledged vision of the goals or mission underlying the project (Pinto \& Slevin, 1988). In addition, De Wit (1988) states that a project is considered to be a success if it meets the original goals and if there is a high level of satisfaction with the 
project outcome among crucial people in the organization, people in the project team, and stakeholders. Hollenbeck, Williams, \& Klein (1989) posited that setting arduous goals rather than undemanding or poorly defined goals leads to elevated accomplishment levels. Moreover, depending on a person's level of commitment and their ability to attain the goal, there is a positive relationship between the difficulty of attaining the goal and participant accomplishments (Locke \& Latham, 2006).

Top management support: The literature review points out several measures of assessing management's support of the project teams, including top management's commitment to providing the necessary resources throughout the development and implementation processes. Top managers can use their authority to help the project and support the project team in the event of a crisis. These indicate the reasonable degree of support the project manager can expect from top management, which is crucial. There seems to be a consensus among the literature reviewed that management support plays a significant role in achieving effectiveness of project implementation (EPI), which includes communication, management commitment, leadership style, managing politics, managing societal demands, and motivation (Jetu \& Riedl, 2013; Yang, Huang, \& Wu, 2011; Yong \& Mustaffa, 2012). The project's usefulness is perceived by beneficiaries, sponsors, the project team, and the project's performance (Kerzner, 2003).

Project schedule/plan: Andersen, Birchall, Jessen, \& Money (2006) revealed that managerial ability to deliver a project was strongly related to the application of strong project management based on planning and cost control methodologies. Moreover, performance monitoring occurs when the original plans created during the first days of a project are used to measure progress against revised and relevant baseline plans (Attarzadeh \& Ow, 2008). Project time is the absolute time calculated as the number of days/weeks from the start to the completion of the project. The speed of project implementation is the relative time (Chan, 2001). In addition, Kariungi (2014) expressed that projects are completed on time due to efficiency and proper utilization of project planning tools. Projects generally fail due to poor planning; constant changes to scope, deadline and budget; and a lack of monitoring and control (Ofori, 2013). Frese \& Sauter (2003) concluded that generally, good planning, clear responsibility and accountability, schedule control, project leadership and governance, and communications are vital areas of successful projects.

Client consultation: Communication, consultation, and active listening to all impacted parties (Ofori, 2013). The "client" here refers to whoever will ultimately be using the result of the project. It could be a customer external to the organization or a department within the company. Because this project is for the client's benefit, close and frequent client consultation is imperative to make sure the efforts remain in line with the client's needs (Pinto \& Slevin, 1988). Khang \& Moe (2008) also believe that effective consultation with stakeholders is necessary for success at each phase of a project.

Personnel: The organization's people represent a crucial situational variable in the implementation process (Hammond, 1979). When implementing a new and unfamiliar project, we cannot always be sure we have the necessary people needed for the project team. Attention to selecting and training key personnel can help to ensure the success of a project (Pinto \& Slevin, 1988). Ofori (2013) described the functional personnel processes as recruitment, selection, and training of the necessary personnel for the project team. In addition, Pinto \& Prescott (1988) justify why 'personnel' did not affect project success and concluded that, in this type of organizational structure, having qualified personnel is usually the rule rather than the exception.

Technical tasks: This refers to the availability of the relevant technology and expertise to accomplish the specific technical requirements (Ofori, 2013). A project's implementation must be managed by people who understand it and have adequate technology available to support it. For the effectiveness of project implementation (EPI), skilled people and proper technology are equally significant (Pinto \& Slevin, 1988). Effective projects are defined through the convergence of the process's ability to meet the project's technical goals without deviating from the constraints of scope, time, and cost; the project's usefulness and performance is perceived by beneficiaries, sponsors and the project team (Kerzner, 2003). The development tools and techniques are designed to aid managers in planning, 
decision making, and controlling project tasks. In general, traditional project management techniques handle complexity through the breakdown of tasks into smaller, simpler, and controllable sequences of actions (De Wit \& Herroelen, 1990). Moreover, work breakdown structure (WBS) when planning complex projects such as new product development, R\&D, and organizational restructuring projects. Tasks and goals should be clear and well defined in advance (Duimering, Ran, Derbentseva, \& Poile, 2006; Dvir, Raz, \& Shenhar, 2003; Pich, Loch, \& Meyer, 2002).

Client Acceptance: The act of "selling" the final product to its ultimate intended users (Ofori, 2013). The effectiveness of project implementation (EPI) should lie with the project management team who should also include the client to ensure project effectiveness. The assertion is that early decision making on a project dictates its effectiveness. The client is responsible for these decisions and therefore has a vital role in determining effectiveness. Completing a project requires input from various groups, including the client, the project team, the parent organization, the producer, and the end user. Each party has specific tasks and responsibilities to fulfil to achieve success (Cori, 1985). The project originates from a requirement to meet a need that exists for the client. These needs may take the form of practical requirements and be in vivid contrast to the clients. Satisfying end users' needs is one facet of quality assurance (Munns \& Bjeirmi, 1996).

Monitoring and evaluating: This refers to the timely provision of comprehensive information at each phase in the implementation process (Ofori, 2013). Essential personnel must receive feedback on how the project is proceeding at each step. Monitoring and evaluating mechanisms allow the project manager to be on top of any problems, oversee any corrective measures, and prevent deficiencies from being overlooked. These control systems ensure quality along the way (Cori, 1985). Prabhakar (2008) pointed out that consistent monitoring and feedback were factors leading to the effectiveness of project implementation. In addition, other factors also play a role in strengthening the monitoring, including frequency of scope monitoring to identify changes, the number of people monitoring the project schedule, and the extent of monitoring to detect cost overruns (Ling, Low, Wang, \& Lim, 2009). Likewise, Ika, Diallo, \& Thuillier (2012) rank monitoring and evaluating as highly significant factors of project success.

Similarly, one of the components to achieve project effectiveness was monitoring project progress (Chin, Spowage, \& Yap, 2012). Project structural capacity and, in particular, data systems and information systems are also necessary for monitoring and evaluating exercises (Hassan, 2013).

Communication: Providing an appropriate network and necessary data for all key actors in the project implementation is essential (Ofori, 2013). As can be seen from the model, communication is a critical component in every factor of the implementation process and must be all-pervading. Communication is essential to the project team, and the rest of the organization, and the client. Project implementation cannot take place in a vacuum; there must be constant communication. Furthermore, relevant information concerning the project must be available to all involved parties (Pinto \& Slevin, 1988). Planning, testing and monitoring the progress of the project work are some of the key processes used to manage the project work (Georgieva \& Allan, 2008). Management's competence, commitment to the project, communication and cooperation with the project teams have a significant contribution to the success of a construction project (Ofori, 2013). Frese \& Sauter (2003) concluded that good planning, clear responsibility and accountability, schedule control, project leadership and governance, and communication are vital for successful projects. Project impact can benefit from rich project communications, which are based on project management methodologies and are more dependent on applying “softer" skills (Andersen et al., 2006).

Troubleshooting: This is the process of handling unexpected crises and deviations from the plan (Ofori, 2013). Constant fine-tuning, adjusting and troubleshooting are required at each step in the implementation process. It is essential to realize that each project team member can function as a detector for problems. Each team should contain technically competent people with a specific assignment to deal with issues if and when they arise (Pinto \& Slevin, 1988). Many researchers assert that the primary problems of project management are not merely technical but also human (Belout \& Gauvreau, 2004; Packendorff, 1995). As a result, the final critical success factor refers to 
the availability of contingency plans, systems or procedures that are in place to handle unexpected crises and deviations from the planned approach involving the dynamics of the organization and the participants' lived experiences (O’Reilly \& Parker, 2013). Many managers make the mistake of not involving members of their project teams in early cooperators' conceptual meetings, assuming they only need to concern themselves with their specific tasks (Pinto \& Slevin, 1988). Higher trust levels among team members will lead to better project performance and facilitate project success (Kadefors, 2004; Wong \& Cheung, 2004). In the context of project management, "trust" is "a decision to become dependent on another in return for the possibility of a shared positive outcome" (Munns, 1995). By focusing on a projects' realities, managers can solve actual problems rather than imagined ones in ideal situations (McKay, Safayeni, \& Buzacott, 1995). From the abovementioned, the theoretical argument presented led to the following propositions and hypotheses:

Proposition 1: There is a positive influence of the citizenship behavior effectiveness (CBE) on the effectiveness of project implementation (EPI).

H1: CBE exerts an extended, significant positive effect on EPI.

Proposition 2: The citizenship behavior effectiveness (CBE) variables exert an extended mediative, positive influence on the relationship among the effectiveness of project implementation (EPI) elements.

H2: EPI exerts an extended mediation effect on the relationship between CBE and Project mission (PM).

H3: EPI exerts an extended mediation effect on the relationship between CBE and Top management support (TMS).

H4: EPI exerts an extended mediation effect on the relationship between CBE and Project schedule/plan (PSP).

H5: EPI exerts an extended mediation effect on the relationship between CBE and Client consultation (CC).

H6: EPI exerts an extended mediation effect on the relationship between CBE and Personnel (PSN).

H7: EPI exerts an extended mediation effect on the relationship between CBE and Technical tasks (TT).

H8: EPI exerts an extended mediation effect on the relationship between CBE and Client acceptance (CA).

H9: EPI exerts an extended mediation effect on the relationship between CBE and Monitoring and evaluating (MFB).

H1O: EPI exerts an extended mediation effect on the relationship between CBE and Communication (COM).

H1 1: EPI exerts an extended mediation effect on the relationship between CBE and Troubleshooting (TBS).

\section{METHODOLOGY}

3.1. Research Conceptual Framework

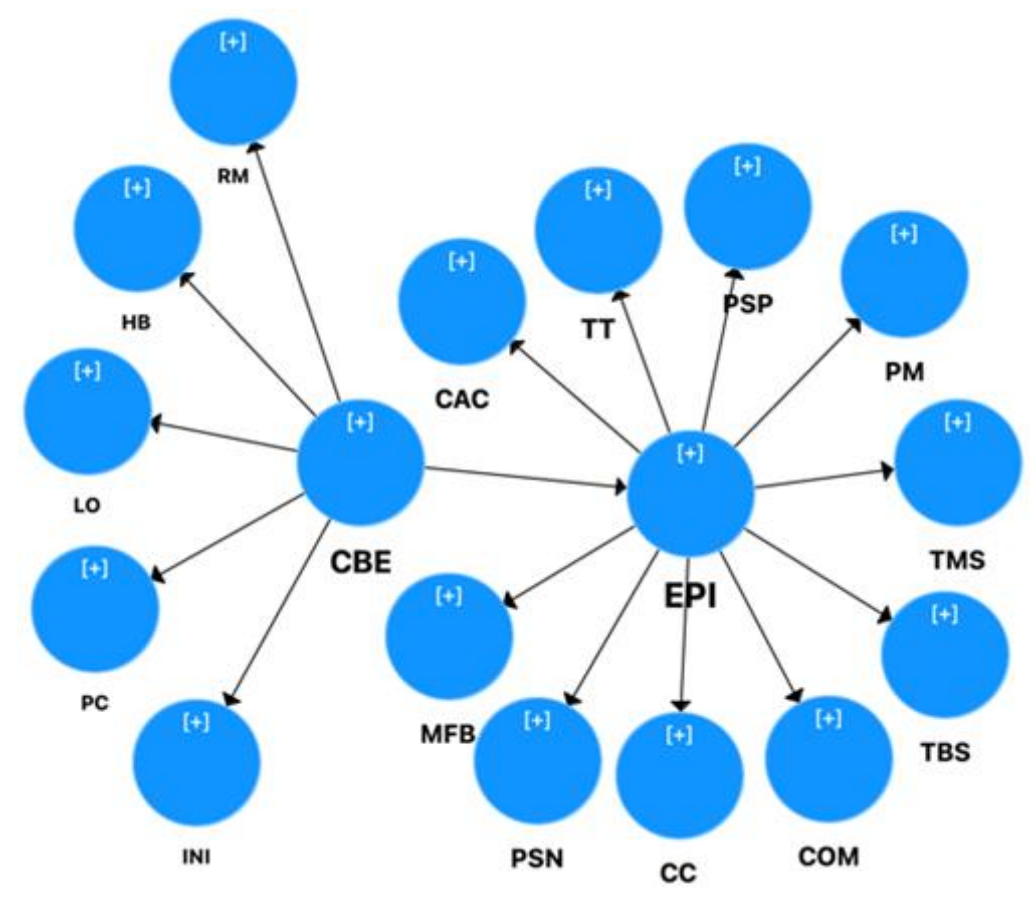

Figure-1. Conceptual framework. 


\subsection{Construct Measurement}

The research model comprises the principles of two constructs, including citizenship behavior effectiveness and the effectiveness of project implementation. Both the constructs fine-tuned the variable observation elements adopted from previous research to ensure that all research measuring elements were valid, representing each construct. The study questionnaire was developed based on the first portion of the theory of citizenship behavior effectiveness (temporary organization); the items were adapted primarily from Braun et al. (2013). In the second portion, the effectiveness of project implementation (project implementation profile (PIP)), the items were adapted primarily from Pinto \& Slevin (1988). A five-point Likert scale $(1=$ strongly disagree to $5=$ strongly agree $)$ was used to measure all the items to represent the level of attitude among the respondents.

\subsection{Sample and Data Collection}

The data collected through questionnaires used a stratified random sample of construction companies working in Thailand's oil and gas industries. The coverage area focused on the provinces with specified industrial areas (Bangkok, Chonburi, Rayong, Ayutthaya, and Saraburi) and employee relations with the organization during "lockdown" to curb the spread of the virus infections. From public service agencies to private enterprises, most workplaces implemented work from home arrangements for most employees. The questionnaires were responded to by the managers of the project management and project administration support divisions. A total of 385 respondents took part in this study. Out of 450 distributed questionnaires, 40 companies responded to the questionnaire, yielding an $85.5 \%$ response rate.

\section{DATA ANALYSIS AND RESULTS}

\subsection{Assessment of Measurement Model, and Quality Criteria}

The assessment of the measurement model was analyzed by considering the results of the descriptive statistics of this study (mean scores, standard deviations, kurtosis, skewness values, and all items of measurement scales). Table 1 displays a normal distribution of data. The kurtosis and skewness values of the measurement model are between \pm 3 , referred to by Kendall, Stuart, \& Ord (1987). The results depict that the skewness scales are between 1.072 and -0.356 , while the value of kurtosis scales is between -0.896 and 1.413 , indicating that no normality assumption violates the sample data.

Table-1. The descriptive statistics of latent variables.

\begin{tabular}{c|c|c|c|c|c}
\hline Item & Median & Min. & Max. & Kurtosis & Skewness \\
\hline HB & -0.531 & -2.165 & 1.103 & -0.896 & -0.356 \\
\hline PC & 0.101 & -3.765 & 1.374 & -0.094 & -0.799 \\
\hline INI & 0.029 & -3.141 & 1.132 & -0.572 & -0.473 \\
\hline LO & 0.022 & -2.708 & 0.906 & 0.120 & -0.927 \\
\hline RM & -0.163 & -2.789 & 1.149 & 0.372 & -0.775 \\
\hline CBE & 0.086 & -2.797 & 1.430 & -0.127 & -0.648 \\
\hline PM & 0.130 & -2.288 & 0.924 & -0.767 & -0.610 \\
\hline TMS & 0.269 & -4.440 & 0.977 & 1.413 & -1.072 \\
\hline PSP & -0.398 & -3.360 & 1.083 & 0.195 & -0.658 \\
\hline CC & -0.573 & -3.027 & 1.054 & -0.665 & -0.455 \\
\hline PSN & -0.335 & -4.253 & 0.971 & 0.957 & -0.994 \\
\hline TT & -0.366 & -3.407 & 1.155 & 0.176 & -0.601 \\
\hline CAC & -0.428 & -3.545 & 1.131 & -0.426 & -0.439 \\
\hline MFB & 0.201 & -3.681 & 1.008 & -0.204 & -0.689 \\
\hline COM & -0.399 & -3.937 & 1.025 & -0.169 & -0.627 \\
\hline TBS & -0.441 & -5.028 & 1.030 & 1.051 & -0.831 \\
\hline EPI & 0.065 & -3.337 & 1.254 & -0.273 & -0.588 \\
\hline & & & & & \\
\hline
\end{tabular}


Various measures were taken to assess the quality of the measurement model. In addition, the multicollinearity test of the predictive components shall not be statistically significantly related to each other. Multicollinearity shows that the antecedent is too highly correlated in the model. In a well-fitting model, the tolerance value (Tolerance) should be higher than 0.20 and the variance inflation factor (VIF) should be less than 5.00 (Hair, Ringle, \& Sarstedt, 2011).

Next, Table 2 shows that various measures also assess the quality of the model. In addition, the multicollinearity test of the predictive components should not be statistically significantly related to each other. There is empirical evidence adopted primarily from that organizational citizenship behavior (OCB) does not just promote effective outcomes. Multicollinearity shows that the antecedent is too highly correlated in the model. In a well-fitting model, the criterion is the variance inflation factor (VIF), which is the ratio (quotient) of the variance of estimating some parameters in a model and should be less than 5.00 (Hair et al., 2011). Therefore, the study confirms the convergent validity and reliability of the measurement model as it was revealed that the predictive component had a VIF between 1.541 and 3.607, which is consistent with the specified criteria. These results mean that the structural equation model for this research does not have multicollinearity coordination problems of external components, as shown in Table 2.

Table-2. Convergent and discriminant validity analyses to assess the measurement model.

\begin{tabular}{|c|c|c|c|c|c|c|c|}
\hline \multirow[t]{2}{*}{ Construct } & \multirow[t]{2}{*}{ Item } & \multirow{2}{*}{$\begin{array}{c}\text { Outer } \\
\text { Loading }\end{array}$} & Collinearity & \multirow{2}{*}{$\begin{array}{c}\text { Cronbach's } \\
\text { Alpha }\end{array}$} & \multirow[t]{2}{*}{ rho_A } & \multirow[t]{2}{*}{$\mathbf{C ~ R}$} & \multirow[t]{2}{*}{ AVE } \\
\hline & & & VIF & & & & \\
\hline \multirow{13}{*}{ CBE } & $\mathrm{HB} 1$ & 0.907 & 1.738 & \multirow{2}{*}{0.789} & \multirow{2}{*}{0.789} & \multirow{2}{*}{0.905} & \multirow{2}{*}{0.826} \\
\hline & $\mathrm{HB} 3$ & 0.910 & 1.738 & & & & \\
\hline & $\mathrm{PC} 1$ & 0.815 & 3.259 & \multirow{4}{*}{0.918} & \multirow{4}{*}{0.918} & \multirow{4}{*}{0.942} & \multirow{4}{*}{0.802} \\
\hline & $\mathrm{PC}_{2}$ & 0.807 & 3.602 & & & & \\
\hline & $\mathrm{PC} 4$ & 0.803 & 3.092 & & & & \\
\hline & $\mathrm{PC} 5$ & 0.805 & 3.607 & & & & \\
\hline & INI 1 & 0.725 & 2.162 & \multirow{3}{*}{0.858} & \multirow{3}{*}{0.859} & \multirow{3}{*}{0.914} & \multirow{3}{*}{0.779} \\
\hline & INI3 & 0.766 & 2.210 & & & & \\
\hline & INI4 & 0.753 & 2.095 & & & & \\
\hline & $\mathrm{LO}_{1}$ & 0.562 & 1.541 & \multirow{2}{*}{0.744} & \multirow{2}{*}{0.744} & \multirow{2}{*}{0.887} & \multirow{2}{*}{0.796} \\
\hline & $\mathrm{LO}_{4}$ & 0.559 & 1.541 & & & & \\
\hline & $\mathrm{RM} 2$ & 0.561 & 1.977 & \multirow{2}{*}{0.826} & \multirow{2}{*}{0.832} & \multirow{2}{*}{0.920} & \multirow{2}{*}{0.851} \\
\hline & RM4 & 0.625 & 1.977 & & & & \\
\hline & PM1 & 0.727 & 2.636 & O 881 & 0881 & 0944 & 0804 \\
\hline & $\mathrm{PM} 2$ & 0.728 & 2.636 & 0.881 & 0.881 & 0.944 & 0.894 \\
\hline & $\mathrm{TMS} 2$ & 0.750 & 1.885 & 0813 & 0813 & 0915 & 0849 \\
\hline & TMS3 & 0.760 & 1.885 & 0.010 & 0.010 & 0.910 & $0.0 \mathrm{~T}$ \\
\hline & PSP1 & 0.754 & 2.211 & 0851 & 0850 & 0930 & 0870 \\
\hline & $\mathrm{PSP} 2$ & 0.788 & 2.211 & 0.851 & 0.852 & 0.930 & 0.870 \\
\hline & $\mathrm{CC}_{2}$ & 0.941 & 2.431 & 0868 & 0868 & 0938 & 0884 \\
\hline & CC3 & 0.939 & 2.431 & 0.808 & 0.808 & 0.938 & 0.884 \\
\hline & PSN 1 & 0.780 & 2.877 & 0894 & 0804 & 0949 & 0904 \\
\hline EPI & $\mathrm{PSN} 2$ & 0.754 & 2.877 & 0.894 & 0.894 & 0.949 & 0.904 \\
\hline & TT1 & 0.779 & 3.153 & 0871 & 0871 & 0939 & 0886 \\
\hline & $\mathrm{TT} 2$ & 0.789 & 3.308 & 0.011 & 0.071 & 0.939 & 0.000 \\
\hline & CAC 1 & 0.947 & 2.674 & 0889 & 0884 & 0945 & 0896 \\
\hline & $\mathrm{CAC}_{2}$ & 0.945 & 2.674 & 0.003 & $0.00 \%$ & $0.9 \% 5$ & 0.890 \\
\hline & $\mathrm{MFB1}$ & 0.730 & 2.105 & $\Omega 840$ & 0844 & 0996 & 0869 \\
\hline & MFB3 & 0.756 & 2.105 & $0.0 \% 0$ & $0.0 \% 1$ & 0.920 & 0.002 \\
\hline & $\mathrm{COM}_{2}$ & 0.953 & 2.969 & & & & \\
\hline & $\mathrm{COM} 3$ & 0.952 & 2.969 & 0.898 & 0.898 & 0.951 & 0.907 \\
\hline & TBS1 & 0.807 & 1.817 & 0803 & 0803 & 0910 & 0835 \\
\hline & TBS3 & 0.802 & 1.817 & 0.000 & 0.000 & 0.710 & 0.000 \\
\hline
\end{tabular}


In addition, convergent and discriminant validity analyses were carried out to assess the measurement model, each construct of composite reliability, and acceptance value criteria of Cronbach's $\alpha$ values higher than 0.7 (Chin, 1998). The composite reliability (CR) values ranged from 0.887 to 0.951 , and Cronbach's $\alpha$ values ranged from 0.744 to 0.918. Meanwhile, all the constructs' factor loadings are above the recommended threshold of 0.6 (Chin, 1998). Additionally, the average variance extracted (AVE) values of the constructs ranged between 0.779 and 0.907 , which is more than the recommended minimum value of 0.5 (Hair, Ringle, \& Sarstedt, 2013). Therefore, the study confirms the convergent validity and reliability of the measurement model, as shown in Table 2.

The Fornell-Larcker criterion was used to assess the measurement model and test the discriminant validity of the square root of the AVE value, as it should be higher than the inter constructs correlation accepted under the quality criteria.

Table-3. Fornell-Larcker criterion.

\begin{tabular}{c|c|c|c|c|c|c|c|c|c}
\hline Item & CAC & CC & COM & HB & INI & LO & MFB & CBE & EPI \\
\hline CAC & 0.946 & & & & & & & & \\
\hline CC & 0.652 & 0.940 & & & & & & & \\
\hline COM & 0.688 & 0.660 & 0.952 & & & & & & \\
\hline HB & 0.480 & 0.447 & 0.550 & 0.909 & & & & & \\
\hline INI & 0.610 & 0.633 & 0.651 & 0.572 & 0.883 & & & & \\
\hline LO & 0.498 & 0.520 & 0.537 & 0.579 & 0.613 & 0.892 & & & \\
\hline MFB & 0.645 & 0.558 & 0.692 & 0.603 & 0.631 & 0.574 & 0.929 & & \\
\hline CBE & 0.641 & 0.652 & 0.720 & 0.760 & 0.848 & 0.819 & 0.697 & 0.735 & \\
\hline EPI & 0.820 & 0.818 & 0.879 & 0.622 & 0.775 & 0.644 & 0.801 & 0.831 & 0.774 \\
\hline
\end{tabular}

Table-3. Continued...

\begin{tabular}{c|c|c|c|c|c|c|c|c}
\hline Item & PC & PM & PSN & PSP & RM & TBS & TMS & TT \\
\hline PC & 0.895 & & & & & & & \\
\hline PM & 0.715 & 0.945 & & & & & & \\
\hline PSN & 0.558 & 0.522 & 0.951 & & & & & \\
\hline PSP & 0.662 & 0.647 & 0.612 & 0.933 & & & & \\
\hline RM & 0.463 & 0.476 & 0.389 & 0.442 & 0.923 & & & \\
\hline TBS & 0.637 & 0.645 & 0.701 & 0.663 & 0.473 & 0.603 & & \\
\hline TMS & 0.563 & 0.592 & 0.676 & 0.682 & 0.471 & 0.514 & 0.562 & \\
\hline TT & 0.534 & 0.553 & 0.657 & 0.668 & 0.353 & 0.470 & 0.615 & 0.627 \\
\hline
\end{tabular}

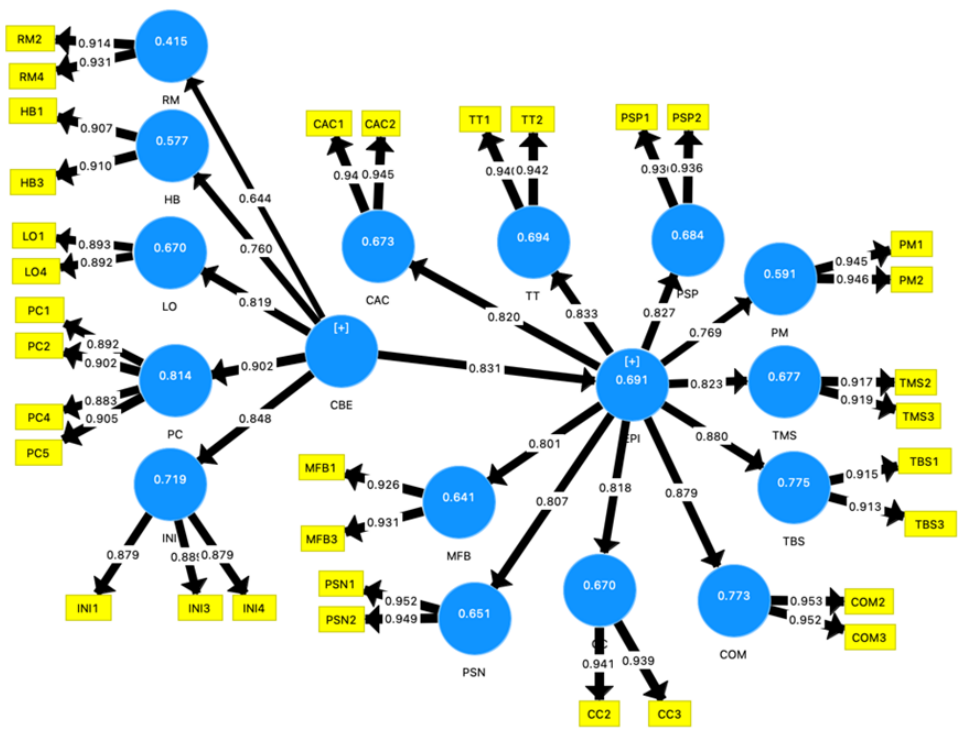

Figure-2. Structural equation modeling analysis. 
4.2.1. Testing of $\mathrm{H} 1$

The path coefficient (B) results are presented in Table 4 and Figure 2 . These descriptions are the final results of each of the variables of the hypotheses. The path coefficients (B), t-statistics and p-values are reported for each.

Table-4. Structural path analysis results (total effects hypothesis).

\begin{tabular}{c|c|c|c|c|c|c}
\hline Hypothesis No. & Construct & $\boldsymbol{\beta}$-Value & Mean (M) & $\begin{array}{c}\text { Standard } \\
\text { Deviation } \\
\text { (STDEV) }\end{array}$ & $\begin{array}{c}\text { T-Statistics } \\
(\mid \boldsymbol{\beta} \text {-Value } \\
\text { /STDEV } \mid)\end{array}$ & P-Value \\
\hline H1 & CBE -> EPI & 0.831 & 0.831 & 0.019 & 43.878 & $* * *$ \\
\hline & CBE -> PM & 0.639 & 0.640 & 0.035 & 18.463 & $* * *$ \\
\hline & CBE -> TMS & 0.684 & 0.684 & 0.025 & 27.896 & $* * *$ \\
\hline & CBE -> PSP & 0.687 & 0.688 & 0.025 & 27.156 & $* * *$ \\
\hline & CBE -> CC & 0.680 & 0.680 & 0.026 & 26.237 & $* * *$ \\
\hline & CBE -> PSN & 0.671 & 0.671 & 0.027 & 24.444 & $* * *$ \\
\hline & $\mathrm{CBE}->$ TT & 0.693 & 0.693 & 0.025 & 28.256 & $* * *$ \\
\hline & $\mathrm{CBE}->$ CAC & 0.682 & 0.682 & 0.025 & 27.451 & $* * *$ \\
\hline & $\mathrm{CBE}->$ MFB & 0.665 & 0.666 & 0.030 & 22.197 & $* * *$ \\
\hline & $\mathrm{CBE}->$ COM & 0.731 & 0.731 & 0.022 & 33.238 & $* * *$ \\
\hline & $\mathrm{CBE}->$ TBS & 0.732 & 0.732 & 0.022 & 34.017 & $* * *$ \\
\hline
\end{tabular}

Notes: *** $P<0.001,{ }^{*} * P<0.01,{ }^{*} P<0.05$.

\subsubsection{Mediation Assessment: Hypothesis testing for $\mathrm{H} 2$ to $\mathrm{H} 1 \mathrm{I}$}

The assessment method here is to assess the extended mediation effect.

Table 5 reveals the existence of a comprehensive mediation effect among constructs and shows the results of the specific indirect effects $\mathrm{H}_{2}$ to $\mathrm{H}_{1} 1$.

Table-5. Structural path analysis results (the specific indirect effects of the hypotheses).

\begin{tabular}{|c|c|c|c|c|c|c|}
\hline $\begin{array}{c}\text { Hypothesis } \\
\text { No. }\end{array}$ & Construct & B-Value & $\begin{array}{c}\text { Mean } \\
(\mathrm{M})\end{array}$ & $\begin{array}{l}\text { Standard } \\
\text { Deviation } \\
(\text { STDEV) }\end{array}$ & $\begin{array}{l}\text { T-Statistic } \\
(\mid \beta-V a l u e \\
\text { /STDEV |) }\end{array}$ & P-Value \\
\hline $\mathrm{H} 2$ & CBE -> EPI -> PM & 0.639 & 0.640 & 0.035 & 18.463 & **** \\
\hline $\mathrm{H} 3$ & CBE $->$ EPI $->$ TMS & 0.684 & 0.684 & 0.025 & 27.896 & **** \\
\hline $\mathrm{H} 4$ & CBE -> EPI -> PSP & 0.687 & 0.688 & 0.025 & 27.156 & **** \\
\hline H5 & $\mathrm{CBE}->\mathrm{EPI}->\mathrm{CC}$ & 0.680 & 0.680 & 0.026 & 26.237 & **** \\
\hline H6 & CBE $->$ EPI $->$ PSN & 0.671 & 0.671 & 0.027 & 24.444 & **** \\
\hline $\mathrm{H} 7$ & CBE $->$ EPI $->$ TT & 0.693 & 0.693 & 0.025 & 28.256 & **** \\
\hline $\mathrm{H} 8$ & $\mathrm{CBE}->\mathrm{EPI}->\mathrm{CAC}$ & 0.682 & 0.682 & 0.025 & 27.451 & **** \\
\hline H9 & CBE $->$ EPI $->$ MFB & 0.665 & 0.666 & 0.030 & 22.197 & **** \\
\hline $\mathrm{H} 1 \mathrm{O}$ & $\mathrm{CBE}->\mathrm{EPI}->\mathrm{COM}$ & 0.731 & 0.731 & 0.022 & 33.238 & **** \\
\hline H11 & CBE $->$ EPI $->$ TBS & 0.732 & 0.732 & 0.022 & 34.017 & **** \\
\hline
\end{tabular}

In the analysis, the $\mathrm{R}$-squared $\left(\mathrm{R}^{2}\right)$ values (determination coefficient) of 0.75 , 0.50 , and 0.25 represent substantial, moderate and weak levels to predict the model's ability. Recommended substantial $\mathrm{R}^{2}$ values are based on those stated by Hair et al. (2013).

Table 6 contains the results of the $\mathrm{R}^{2}$ values, which, in this study, revealed that the standard path coefficient for each relationship between exogenous and endogenous variables increase the predictive ability of the model. All $\mathrm{R}^{2}$ values (determination coefficient) are considered acceptable for structural equation modeling (SEM). 
Table-6. Variance explained: R-squared $\left(\mathrm{R}^{2}\right)$ values (determination coefficient).

\begin{tabular}{c|c|c}
\hline Dependent construct & R-squared $\left(\mathbf{R}^{\mathbf{}}\right)$ & Adjusted R-Squared \\
\hline CAC & 0.673 & 0.672 \\
\hline CC & 0.670 & 0.669 \\
\hline COM & 0.773 & 0.773 \\
\hline HB & 0.577 & 0.576 \\
\hline INI & 0.719 & 0.719 \\
\hline LO & 0.670 & 0.669 \\
\hline MFB & 0.641 & 0.640 \\
\hline EPI & 0.691 & 0.690 \\
\hline PC & 0.814 & 0.813 \\
\hline PM & 0.591 & 0.590 \\
\hline PSN & 0.651 & 0.651 \\
\hline PSP & 0.684 & 0.683 \\
\hline RM & 0.415 & 0.413 \\
\hline TBS & 0.775 & 0.775 \\
\hline TMS & 0.677 & 0.676 \\
\hline TT & 0.694 & 0.694 \\
\hline
\end{tabular}

\section{DISCUSSION AND CONCLUSION}

\subsection{Discussion and Conclusion}

Proposition 1: There is a positive influence of citizenship behavior effectiveness (CBE) on the effectiveness of project implementation (EPI) (Autry et al., 2008; Braun et al., 2013; De Wit, 1988; Mir \& Pinnington, 2014; Munns \& Bjeirmi, 1996; Pinto \& Slevin, 1988; Podsakoff et al., 2000). This study reflected a response to citizenship behavior effectiveness in temporary organizations and the effectiveness of project implementation (EPI) literature, addressing the need to analyze the effects of project mission (PM), top management support (TMS). project schedule/plan (PSP), client consultation (CC), personnel (PSN), technical tasks (TT), client acceptance (CAC), monitoring and evaluating (MFB), communication (COM), and troubleshooting (TBS). The results revealed a positive effect between citizenship behavior effectiveness and the effectiveness of project implementation (EPI), which supports Hypothesis 1. Citizenship behavior effectiveness was represented on these the subscale of helping behaviors (HB), which refers to the help given to project staff when they have a heavy workload. The next factor, project loyalty (LO), defended the project if criticized by external parties. Project-based compliance (PC), which is the responsibility of the on manager, is to ensure that the project team members strictly follow the rules and instructions that apply to the project and that they conform to all contractual obligations. Individual initiative (INI) refers to employees applying their ideas and suggestions to the project work, even when not explicitly requested. Last, relationship maintenance is defined as effectively maintaining contact with particular employees even when not participating in the same project. These factors are critical in supporting CBE and its significant positive effect on EPI in the conceptual framework.

Proposition 2: The citizenship behaviors effectiveness (CBE) variables have exerted an extended positive mediation influence on the relationship among the effectiveness of project implementation (EPI) elements, which were tested via hypotheses $\mathrm{H}_{2}-\mathrm{H}_{1} 1$ in terms of the study's objectives.

Testing Hypothesis 2: The results found that there is an extending mediation effect on the relationship between $\mathrm{CBE}$ and $\mathrm{PM}$, and $\mathrm{H} 2$ is supported. It is important to clarify the project goals and ensure that they are communicated clearly to the employees. Literature by Pinto \& Slevin (1988); Hollenbeck et al. (1989); Locke \& Latham (2006); De Wit (1988); Braun et al. (2013); and Podsakoff et al. (2000) also support this finding.

Testing Hypothesis 3: The results revealed that EPI exerts an extending mediation effect on the relationship between CBE and TMS. Therefore, supporting this finding, top management support (TMS) refers to the willingness demonstrated by top management to provide the necessary resources and authority for project success, such as the amount of money allocated to the project, time, workforce, and equipment. Literature by Pinto \& Slevin 
(1988); Jetu \& Riedl (2013); Yong \& Mustaffa (2012); Attarzadeh \& Ow (2008); Georgieva \& Allan (2008); Yang et al. (2011); Kerzner (2003); Braun et al. (2013); Podsakoff et al. (2000) also supports this finding.

Testing Hypothesis H4: The results revealed that EPI exerts an extending mediation effect on the relationship between CBE and PSP due to a detailed specification being put in place of the individual steps required to implement and complete a project. It is measured based on a detailed plan which includes time schedules, milestones, workforce requirements, and equipment requirements. Literature by Pinto \& Slevin (1988); Andersen et al. (2006); Attarzadeh \& Ow (2008); Chan (2001); Kariungi (2014); Frese \& Sauter (2003); Ofori (2013); Braun et al. (2013); and Podsakoff et al. (2000) support this finding.

Testing Hypothesis 5: The results found that EPI exerts through an extending mediation effect on the relationship between $\mathrm{CBE}$ and CC. Communication, consultation, and active listening for all relevant parties are emphasized, and it is measured based on an understanding of the needs of those who will use the project. Literature by Pinto \& Slevin (1988); Ofori (2013); Khang \& Moe (2008); Braun et al. (2013); and Podsakoff et al. (2000) support this finding.

Testing Hypothesis 6: The results support the hypotheses that EPI exerts an extending mediation effect on the relationship between CBE and PSN. The recruitment, selection, and training of the necessary personnel for the project team was examined, and the project team includes personnel with adequate technical and managerial skills. Literature by Pinto \& Slevin (1988); Ofori (2013); Braun et al. (2013); and Podsakoff et al. (2000) support this finding.

Testing Hypothesis 7: The results support the statement that EPI exerts an extending mediation effect on the relationship between CBE and TT. It is necessary to seek the availability of the required technology to accomplish specific tasks. The appropriate technology, tools, project management software, and training programs need to be selected for project success. Literature by Pinto \& Slevin (1988); Ofori (2013); Kerzner (2003); De Wit \& Herroelen (1990); Duimering et al. (2006); Braun et al. (2013); and Podsakoff et al. (2000) support this finding.

Testing Hypothesis 8: The results support the hypothesis that EPI exerts an extending mediation effect on the relationship between CBE and CAC. For the satisfactory delivery of the completed project to the intended users, an adequate project presentation must be developed for clients. Literature by Pinto \& Slevin (1988); Munns \& Bjeirmi (1996); Ofori (2013); Braun et al. (2013); and Podsakoff et al. (2000) also support this finding.

Testing Hypothesis 9: The results support the statement that EPI exerts an extending mediation effect on the relationship between $\mathrm{CBE}$ and $\mathrm{MFB}$. The actual progress is regularly compared against the project schedule. Literature by Pinto \& Slevin (1988); Prabhakar (2008); Ling et al. (2009); Papke-Shields, Beise, \& Quan (2010); Ika et al. (2012); Chin (1998); Hassan (2013); Ofori (2013); Braun et al. (2013); and Podsakoff et al. (2000) support this finding.

Testing Hypothesis 10: The results revealed that EPI exerts an extending mediation effect on the relationship between $\mathrm{CBE}$ and COM. This refers to the provision of an appropriate network and necessary data for all key actors in the project's implementation. The reasons for any changes to existing policies and procedures must be explained to members of the project team, other parties who may be affected by the changes, and upper management. Literature by Pinto \& Slevin (1988); Georgieva \& Allan (2008); Frese \& Sauter (2003); Andersen et al. (2006); Ofori (2013); Braun et al. (2013); and Podsakoff et al. (2000) support this finding.

Testing hypothesis H1O. The results revealed supported that exerts through an extending mediation effect on the relationship between CBE and COM. The provision of an appropriate network and necessary data to all key actors in the project's implementation. The reasons for any changes to existing policies procedures have remained explained to members of the project team, other groups affected by changes, upper management. Literature of supported this finding.

Testing hypothesis H11. The results revealed supported that exerts through Testing Hypothesis 11: The results revealed that EPI exerts an extending mediation effect on the relationship between CBE and TBS. The ability to 
handle unexpected crises and deviations from the project plan addresses problem areas by discussing them with the appropriate personnel and identifying a solution strategy. Literature by Pinto \& Slevin (1988); Belout \& Gauvreau (2004); Packendorff (1995); Ofori (2013); Kadefors (2004); Munns (1995); Braun et al. (2013); and Podsakoff et al. (2000) support this finding.

\subsection{Theoretical Implication}

For academic purposes, the research results may be used as a guideline for further research relevant to this particular topic. The conceptual framework of the effectiveness of project implementation shows that it exerts an extended mediation effect on the relationship between citizenship behavior effectiveness. The observable variables used are: project mission, top management support, project schedule/plan, client consultation, personnel, technical tasks, client acceptance, monitoring and evaluating, communication, and troubleshooting, which all produce positive and significant effects in the construction projects of the oil and gas industry. To this end, regarding the contribution of each construct to the conceptual model, this study found advantages of citizenship behavior effectiveness (CBE) for projects in temporary organizations that consist of subscales of organizational citizenship behavior - helping behaviors, project loyalty, project-based compliance, individual initiative, and relationship maintenance - all of which are vital to support the conceptual framework. Hence, the research results can provide more understanding concerning construction companies working in Thailand's oil and gas industries, including when organizations continue to operate during adverse situations, such as lockdown, to curb the spread of virus infections.

\subsection{Practical Implication}

The findings of this study have implications for construction companies working in Thailand's oil and gas industries. In addition, inspiration can be motivated by articulating the importance of what corporate members can do to facilitate the achievement of organizational objectives. This research has demonstrated proof that the accomplishment of the effectiveness of project implementation (EPI) will lead to successful project development and execution. Similarly, this study has proposed that citizenship behavior effectiveness (CBE) makes projects (in temporary organizations) more productive and solid. Through citizenship behavior effectiveness (CBE), the project team can implement policies and procedures that drives EPI regarding sensitivity to members' needs.

\subsection{Limitations and Future Research}

The limitations of this study are that only two constructs have been examined in the analysis, and the study was restricted solely to construction companies working in oil and gas industries in Thailand. Future studies should consider increasing the construct that the leader-member exchange (LMX) relationship to predict better performance and encourage organizational citizenship behaviors (OCB).

Funding: This study received no specific financial support.

Competing Interests: The authors declare that they have no competing interests.

Acknowledgement: Both authors contributed equally to the conception and design of the study.

\section{REFERENCES}

Andersen, E. S., Birchall, D., Jessen, S. A., \& Money, A. H. (2006). Exploring project success. Baltic Journal of Management, 1(2), 127-147. Available at: 10.1108/17465260610663854.

Attarzadeh, I., \& Ow, S. H. (2008). Project management practices: The criteria for success or failure. Communications of the IBIMA, 1(28), 234-241. 
Autry, C. W., Skinner, L. R., \& Lamb, C. W. (2008). Interorganizational citizenship behaviors: An empirical study. Journal of Business Logistics, 29(2), 53-74. Available at: https://doi.org/10.1002/j.2158-1592.2008.tbo0087.x.

Belout, A., \& Gauvreau, C. (2004). Factors influencing project success: The impact of human resource management. International Journal of Project Management, 22(1), 1-11. Available at: https://doi.org/10.1016/s0263-7863(03)00003-6.

Blatt, R. (2008). Organizational citizenship behavior of temporary knowledge employees. Organization Studies, 29(6), 849-866. Available at: https://doi.org/10.1177/0170840608088704.

Bolino, M. C., Turnley, W. H., \& Bloodgood, J. M. (2002). Citizenship behavior and the creation of social capital in organizations. Academy of Management Review, 27(4), 505-522. Available at: https://doi.org/10.1177/0170840608088704.

Borman, W. C., \& Motowidlo, S. J. (1997). Task performance and contextual performance: The meaning for personnel selection research. Human Performance, 1O(2), 99-109. Available at: https://doi.org/10.1207/s15327043hup1002_3.

Braun, T., Ferreira, A. I., \& Sydow, J. (2013). Citizenship behavior and effectiveness in temporary organizations. International Journal of Project Management, 31(6), 862-876. Available at: https://doi.org/10.1016/j.ijproman.2012.09.003.

Chan, A. P. (2001). Time-cost relationship of public sector projects in Malaysia. International Journal of Project Management, 19(4), 223-229. Available at: https://doi.org/10.1016/s0263-7863(99)00072-1.

Chin, W. W. (1998). The partial least squares approach to structural equation modeling. Modern Methods for Business Research, 295(2), 295-336.

Chin, C., Spowage, A., \& Yap, E. (2012). Project management methodologies: A comparative analysis. Journal for the Advancement of Performance Information and Value, 4(1), 106-106.

Cori, K. A. (1985). Fundamentals of master scheduling for the project manager: Project Management Institute.

De Wit, A. (1988). Measurement of project success. International Journal of Project Management, 6(3), 164-170. Available at: https://doi.org/10.1016/0263-7863(88)90043-9.

De Wit, J., \& Herroelen, W. (1990). An evaluation of microcomputer-based software packages for project management. European Journal of Operational Research, 49(1), 102-139. Available at: https://doi.org/10.1016/0377-2217(90)90124-t.

Duimering, P. R., Ran, B., Derbentseva, N., \& Poile, C. (2006). The effects of ambiguity on project task structure in new product development. Knowledge and Process Management, 13(4), 239-251. Available at: https://doi.org/10.1002/kpm.260.

Dvir, D., Raz, T., \& Shenhar, A. J. (2003). An empirical analysis of the relationship between project planning and project success. International Journal of Project Management, 21(2), 89-95. Available at: https://doi.org/10.1016/s0263-7863(02)000121.

Frese, R., \& Sauter, V. (2003). Project success and failure: What is success, what is failure, and how can you improve your odds for success. Retrieved from: http://www. umsl. edu/ sauterv/analysis/6840_fo3_papers/frese/.

Georgieva, S., \& Allan, G. (2008). Best practices in project management through a grounded theory lens. Electronic Journal of Business Research Methods, 6(1), 43-52.

Griffin, D., \& Denholm, J. (2020). This Isn't the first global pandemic, and it won't be the last. Here's What We've Learned from 4. Others Throughout History. The Conversation, April 17, 2020. Retrieved from: https://theconversation.com/thisisnt-the-first-global-pandemic-and-it-wont-be-the-last-heres-what-weve-learned-from-4-others-throughout-history136231.

Hair, J. F., Ringle, C. M., \& Sarstedt, M. (2011). PLS-SEM: Indeed a silver bullet. Journal of Marketing theory and Practice, 19(2), 139-152. Available at: https://doi.org/10.2753/mtp1069-6679190202.

Hair, J. F., Ringle, C. M., \& Sarstedt, M. (2013). Partial least squares structural equation modeling: Rigorous applications, better results and higher acceptance. Long Range Planning, 46(1-2), 1-12. Available at: https://doi.org/10.1016/j.lrp.2013.01.001.

Hammond, J. S. (1979). A practitioner-oriented framework for implementation in the implementation of management science, ed. Doktor, R., Schultz, R. L. and Slevin, D. P (pp. 35-62). New York: North-Holland. 
Hassan, A. I. (2013). An investigation of structural capacity as a component of monitoring and evaluation in project success of road construction projects in Kenya. International Journal of Academic Research in Business and Social Sciences, 3(8), 443. Available at: https://doi.org/10.6007/ijarbss/v3-i8/169.

Hollenbeck, J. R., Williams, C. R., \& Klein, H. J. (1989). An empirical examination of the antecedents of commitment to difficult goals. Journal of Applied Psychology, 74(1), 18-23. Available at: https://doi.org/10.1037/002 1-9010.74.1.18.

Ika, L. A., Diallo, A., \& Thuillier, D. (2012). Critical success factors for World Bank projects: An empirical investigation. International Journal of Project Management, 30(1), 105-116. Available at: https://doi.org/10.1016/j.ijproman.2011.03.005.

Jetu, F. T., \& Riedl, R. (2013). Cultural values influencing project team success. International Journal of Managing Projects in Business, 6(3), 425-456. Available at: https://doi.org/10.1108/ijmpb-11-2011-0072.

Kadefors, A. (2004). Trust in project relationships-inside the black box. International Journal of Project Management, 22(3), 175182. Available at: https://doi.org/10.1016/s0263-7863(03)00031-0.

Kariungi, S. M. (2014). Determinants of timely completion of projects in Kenya: A case of Kenya power and lighting company, Thika. ABC Journal of Advanced Research, 3(2), 75-86. Available at: https://doi.org/10.18034/abcjar.v3i2.33.

Kendall, M. G., Stuart, A., \& Ord, J. K. (1987). Kendall's advanced theory of statistics (6th ed.). New York: Oxford University Press, Inc.

Kerzner, H. (2003). Advanced project management: Best practices on implementation (2nd ed.): John Wiley \& Sons.

Khang, D. B., \& Moe, T. L. (2008). Success criteria and factors for international development projects: A life-cycle-based framework. Project Management Journal, 39(1), 72-84.

Ling, F. Y. Y., Low, S. P., Wang, S. Q., \& Lim, H. H. (2009). Key project management practices affecting Singaporean firms' project performance in China. International Journal of Project Management, 27(1), 59-71. Available at: https://doi.org/10.1016/j.ijproman.2007.10.004.

Locke, E. A., \& Latham, G. P. (2006). New directions in goal-setting theory. Current Directions in Psychological Science, 15(5), 265268.

McKay, K. N., Safayeni, F. R., \& Buzacott, J. A. (1995). Schedulers \& planners: What and how can we learn from them. In: Brown D.E., Scherer W.T. (eds) Intelligent Scheduling Systems. Operations Research / Computer Science Interfaces Series (Vol. 3). Boston, MA: Springer.

Mir, F. A., \& Pinnington, A. H. (2014). Exploring the value of project management: linking project management performance and project success. International Journal of Project Management, 32(2), 202-217. Available at: https://doi.org/10.1016/j.ijproman.2013.05.012.

Munns, A. (1995). Potential influence of trust on the successful completion of a project. International Journal of Project Management, 13(1), 19-24. Available at: https://doi.org/10.1016/0263-7863(95)95699-e.

Munns, A. K., \& Bjeirmi, B. F. (1996). The role of project management in achieving project success. International Journal of Project Management, 14(2), 81-87. Available at: https://doi.org/10.1016/0263-7863(95)00057-7.

O'Reilly, M., \& Parker, N. (2013). 'Unsatisfactory Saturation': a critical exploration of the notion of saturated sample sizes in qualitative research. Qualitative Research, 13(2), 190-197. Available at: https://doi.org/10.1 177/1468794112446106.

Ofori, D. F. (2013). Project management practices and critical success factors-A developing country perspective. International Journal of Business and Management, 8(21), 14-31. Available at: https://doi.org/10.5539/ijbm.v8n2 1p14.

Organ, D. W., Podsakoff, P. M., \& MacKenzie, S. B. (2005). Organizational citizenship behavior: Its nature, antecedents, and consequences.

Retrieved

from:

https://books.google.co.th/books?hl=en\&lr=\&id=wXiHCgAAQBAJ\&oi=fnd\&pg=PP $1 \& d q=$ Organ, + D. + W., + Podsak off,+P.+M.,+\%26+MacKenzie,+S.+B.+(2005).+Organizational+citizenship+behavior:+Its+nature,+antecedents,+and + consequences.

Packendorff, J. (1995). Inquiring into the temporary organization: New directions for project management research. Scandinavian Journal of Management, $11(4)$, 319-333. Available at: https://doi.org/10.1016/0956-522 1(95)O0018-q. 
Papke-Shields, K. E., Beise, C., \& Quan, J. (2010). Do project managers practice what they preach, and does it matter to project success? International Journal of Project Management, 28(7), 650-662. Available at: https://doi.org/10.1016/j.ijproman.2009.11.002.

Pich, M. T., Loch, C. H., \& Meyer, A. D. (2002). On uncertainty, ambiguity, and complexity in project management. Management Science, 48(8), 1008-1023. Available at: https://doi.org/10.1287/mnsc.48.8.1008.163.

Pinto, J. K., \& Prescott, J. E. (1988). Variations in critical success factors over the stages in the project life cycle. Journal of Management, 14(1), 5-18.

Pinto, J. K., \& Slevin, D. P. (1988). 20. Critical success factors in effective project implementation. Project Management Handbook, 479, 167-190. Available at: https://doi.org/10.1002/9780470172353.ch20.

Podsakoff, P. M., MacKenzie, S. B., Moorman, R. H., \& Fetter, R. (1990). Transformational leader behaviors and their effects on followers' trust in leader, satisfaction, and organizational citizenship behaviors. The Leadership Quarterly, 1(2), 107-142.

Podsakoff, P. M., MacKenzie, S. B., Paine, J. B., \& Bachrach, D. G. (2000). Organizational citizenship behaviors: A critical review of the theoretical and empirical literature and suggestions for future research. Journal of Management, 26(3), 513-563. Available at: https://doi.org/10.1177/014920630002600307.

Prabhakar, G. P. (2008). What is project success: A literature review. International Journal of Business and Management, 3(9), 3-10. Available at: https://doi.org/10.5539/ijbm.v3n9p3.

Rhoades, L., \& Eisenberger, R. (2002). Perceived organizational support: A review of the literature. Journal of Applied Psychology, $87(4), 698$.

Richter, A. (2020). Locked-down digital work. International Journal of Information Management, 55, 102157. Available at: https://doi.org/10.1016/j.ijinfomgt.2020.102157.

Singh, N., Tang, Y., Zhang, Z., \& Zheng, C. (2020). COVID-19 waste management: effective and successful measures in Wuhan, China. Resources, Conservation, and Recycling, 163, 105071. Available at: https://doi.org/10.1016/j.resconrec.2020.105071.

Staufenbiel, T., \& Hartz, C. (2000). Organizational citizenship behavior: Entwicklung und erste validierung eines meßinstruments. Diagnostica, 46(2), 73-83. Available at: https://psycnet.apa.org/doi/10.1026/0012-1924.46.2.73.

Tubadji, A., Boy, F., \& Webber, D. (2020). Narrative economics, public policy and mental health. Center for Economic Policy Research, 20, 109-131.

Van Dyne, L., Graham, J. W., \& Dienesch, R. M. (1994). Organizational citizenship behavior: Construct redefinition, measurement, and validation. Academy of Management Journal, 37(4), 765-802. Available at: https://doi.org/10.5465/256600.

Wong, P. S.-P., \& Cheung, S.-O. (2004). Trust in construction partnering: Views from parties of the partnering dance. International Journal of Project Management, 22(6), 437-446. Available at: https://doi.org/10.1016/j.ijproman.2004.01.001.

Wong, Y.-T., Ngo, H.-Y., \& Wong, C.-S. (2006). Perceived organizational justice, trust, and OCB: A study of Chinese workers in joint ventures and state-owned enterprises. Journal of World Business, 41(4), 344-355. Available at: https://doi.org/10.1016/j.jwb.2006.08.003.

Yang, L.-R., Huang, C.-F., \& Wu, K.-S. (2011). The association among project manager's leadership style, teamwork and project success. International Journal of Project Management, 29(3), 258-267. Available at: https://doi.org/10.1016/j.ijproman.2010.03.006.

Yong, Y. C., \& Mustaffa, N. E. (2012). Analysis of factors critical to construction project success in Malaysia. Engineering, Construction and Architectural Management, 19(5), 543-556. 